
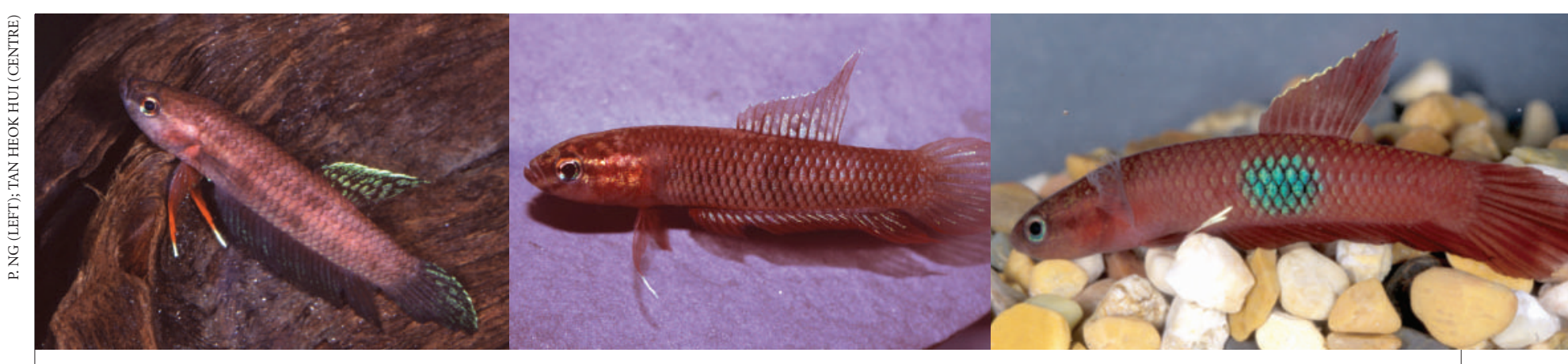

\title{
A tragedy with many players
}

\author{
Peter $\mathrm{Ng}$ is a man with a mission: to catalogue the huge diversity of life \\ dwelling in habitats long dismissed as uninteresting. It's a race against time, \\ he tells Carina Dennis and Peter Aldhous.
}

A tropical peat swamp is not a welcoming place. Its acidic waters sting every tiny scratch on your body. Hold your hands just beneath the surface and you can't see them through the tannin-laden water. The only bonus is that leeches don't fancy the murk. But Peter Ng, a taxonomist and conservation biologist at the National University of Singapore, loves getting up to his armpits in the mire.

$\mathrm{Ng}$ has discovered that the peat swamps of southeast Asia are teeming with rare species of fish and crustaceans, many of which are new to science. "Peat swamps have been badly neglected," says $\mathrm{Ng}$, who pulls out novel specimens on nearly every dip into these hostile waters. His team has found a treasure trove of biodiversity in other unlikely places too, including the broken rubble of dead coral found off tropical beaches.

Now $\mathrm{Ng}$ is engaged in a race to catalogue these neglected faunas before many of them are wiped out by Asia's relentless economic development. The peat swamps, in particular, are being drained as fast as he can sample them, sometimes for urban or agricultural development, at other times — in a bitter irony - under the guise of 'environmental improvement'.

The rich faunas found in such neglected habitats underline a growing realization that conservation biologists really know very little about our planet's biodiversity (see 'Hyperdiversity, or hype?', overleaf). But Ng's quest is driven by more than academic interest. "Scientists and environmental managers need to know these habitats exist and that they deserve to be conserved," he says. "If they are lost through ignorance or misinfor- mation, then it will be a terrible tragedy."

Ng's excitement about peat swamps was first fired in the early 1990s, when his surveys of the North Selangor swamp in Malaysia turned up some unexpected finds. Wading through the muck, his team stumbled on several species of an elusive genus of catfish called Encheloclarias ${ }^{1}$. The last time anyone reported finding such a fish was in the 1930s.

The $\mathrm{pH}$ of such swamp waters can be as low as $3-$ about the same as vinegar. "Until recently, peat swamps were assumed to be hostile, acidic places where the biodiversity was low," says $\mathrm{Ng}$. "But that's because no one had actually jumped in." After taking the plunge into numerous swamps on the Malay Peninsula and the islands of Borneo and Sumatra, Ng's team has found some 80 fish new to science, bringing the estimate of the total number of species in the swamps to 200-300. "My students say they have too much to study," he says. A high proportion of the species are exclusive to the peat-swamp environment ${ }^{2}$.

\section{Hide and seek}

It isn't easy pulling these creatures from the mire. Many of the fish and crustaceans hide in crevices in the peat, rather than swimming in the watery channels that run through it. $\mathrm{Ng}$ has to wade into the murky water holding a net, while his larger colleague, Maurice Kottelat, jumps up and down on the banks. "Maurice does his rain dance," says Ng — and that's enough to startle the creatures out of the peat. If $\mathrm{Ng}$ wants to sample all of the species present, including amphibians, he has to collect at night as well. Wading in a swamp in pitch darkness isn't for the easily spooked, he says.
"I'm interested in fish in places where people haven't been," says Kottelat, who is president of the European Ichthyological Society and is based in Cornol, Switzerland. Some of the fish they have found in the swamps - including colourful species of Betta fighting fish, popular with the aquarium trade $^{3}$ — have thrown up some intriguing mysteries. "Why they should be so colourful in such black water is the milliondollar question," Ng says.

$\mathrm{Ng}$ doesn't spend all his time in the field wading chest-deep in fetid swamps. Sometimes his trips take him to much more pleasant destinations, including the idyllic sandy beaches of the US-controlled island of Guam, some 2,000 kilometres east of the Philippines. There he studies another overlooked habitat: the piles of broken coral rubble that lie just a few tens of metres from the shore.

If you swim from a tropical beach to its fringing reef, you first pass over expanses of this rubble, created by storms and the ravages of time. Many naturalists make this journey time and again, lured by the stunning array of fish and other animals in the reef itself. But few pause to give the rubble a second thought. "It looks like a desert, almost," says $\mathrm{Ng}$.

The rubble piles might still be dismissed

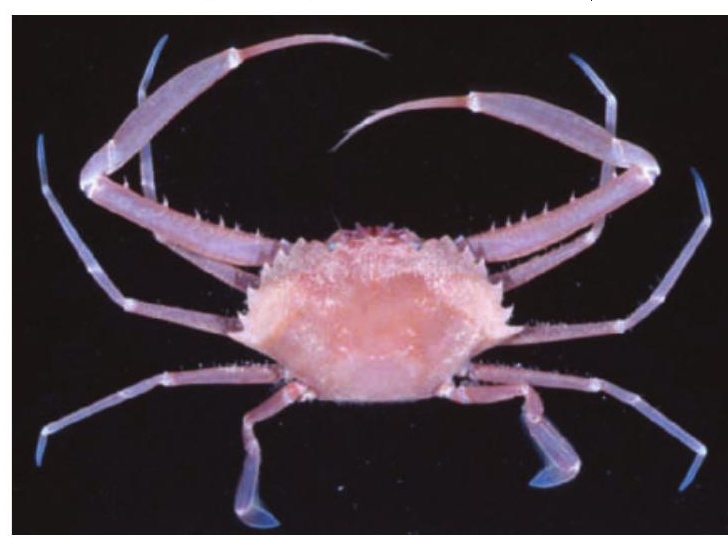


their faunas are poorly studied" "Limestone hills are hotspots of richness, but this has only really been appreciated recently," says Tony Whitten, a biodiversity specialist with the World Bank, based in Washington DC.

The forests that grow above the limestone are rapidly being cleared, which dries out the rock, destroying its subterranean ecosystem. Ecologists studying the caves often find themselves side-by-side — literally — with developers or cement companies mining the hills for raw material. "We'll be carefully collecting our samples, trying not to damage the habitat, and a few hundred metres further on, there's a guy busy with a chainsaw," says Jaap Vermeulen, a collaborator of Ng's at the Singapore Botanic Gardens, who specializes in the taxonomy of snails.

\section{Vanishing world}

Living in the concrete jungle of Singapore, $\mathrm{Ng}$ knows all too well the consequences of unfettered development. Last year, he published a paper in Nature ${ }^{8}$ that used the detailed records made by British colonial naturalists to document the extinctions that have occurred since most of Singapore's forests were cut down. Extrapolating from these data, $\mathrm{Ng}$ and his colleagues concluded that up to $42 \%$ of the species currently in southeast Asia's forests will disappear over the next century if habitat destruction continues at its present rate. About half of these will be global extinctions, as the species are not found elsewhere.

The race to catalogue biodiversity before it disappears is particularly intense in the peat swamps, which are disappearing at a frightening rate. The drainage is even affecting neighbouring bits of forest; dried peat bogs have fuelled huge fires that have razed some areas.

When he talks about the threats to the peat ecosystems, Ng's natural enthusiasm can't hide a deep melancholy. He has become

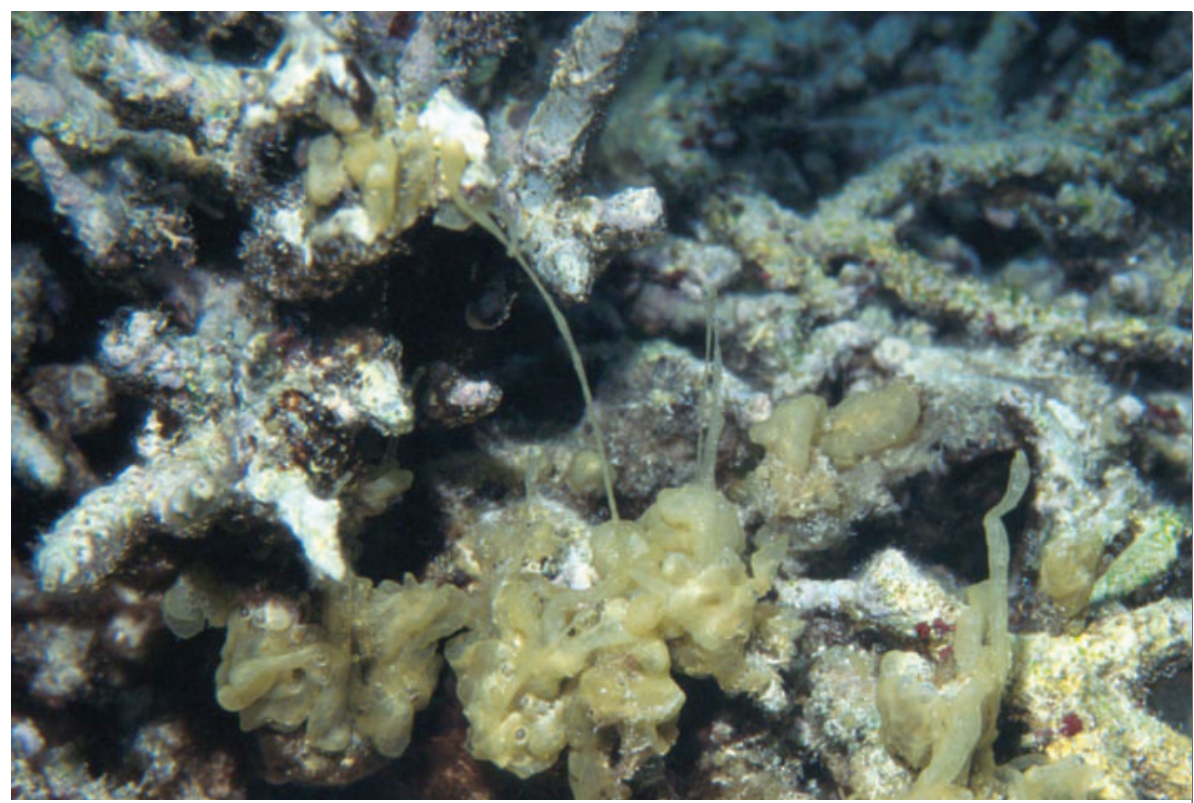

Coral rubble used to be ignored, but it offers researchers access to creatures that live deep within a reef.

a reluctant ambulance chaser, rushing in to sample sites earmarked for development. The collecting methods that Ng's team uses in such cases are severe and destructive. "We call them salvage operations," he says. "We catch whatever is scientifically valuable, knowing full well that there is no tomorrow. It is a very rotten feeling."

$\mathrm{Ng}$ hopes his work will counter the ignorance that underlies the blase destruction of these habitats. Officials and developers argue that there is no point conserving the swamps because there is 'nothing' there. "These places don't have big, sexy animals," Ng concedes. "But in almost all cases, when they say a place is species-poor, they're wrong."

He remains gloomy about the chances of protecting the remaining swamps from the tide of development. But at the very least, $\mathrm{Ng}$ is determined to reveal for future generations the true magnitude of the devastation that is now being wrought. "The story is much more tragic once you know the characters," he says.

Carina Dennis is Nature's Australasian correspondent; Peter Aldhous is Nature's chief news \& features editor.

1. Ng, P. K. L. \& Lim, K. K. P. Ichthyol. Explor. Freshwaters 4, 21-37 (1993).

2. Ng, P. K. L. Wallacea $73,1-5$ (1994)

3. Kottelat, M. \& Ng, P. K. L. Ichthyol. Explor. Freshwaters 5, 65-78 (1994).

4. Paulay, G. Micronesica 35-36, 3-25 (2003).

5. Paulay, G., Kropp, R., Ng, P. K. L. \& Eldredge, L. G. Micronesica 35-36, 458-517 (2003).

6. Ng, P. K. L. \& Takeda, M. Micronesica 35-36, 419-432 (2003).

7. Vermeulen, J. \& Whitten, T. Biodiversity and Cultural Property in the Management of Limestone Resources — Lessons From East Asia (World Bank, Washington DC, 1999).

8. Brook, B. W., Sodhi, N. S. \& Ng, P. K. L. Nature 424, $420-423(2003)$

9. Boucher, G. \& Lambshead, P. J. D. Conserv. Biol. 9 , 1594-1604 (1995).

10. Lambshead, P. J. D. et al. BMC Ecol. 3, 1 (2003).

11. Lambshead, P. J. D. \& Boucher, G. J. Biogeogr. 30, $475-485$ (2003).

12. Gray, J. S. Mar. Ecol. Prog. Ser. 112, 205-209 (1994).

\section{Hyperdiversity, or hype?}

Back in the mid-1990s, John Lambshead was a cheerleader for a radical idea: that the mud of the ocean's depths is every bit as rich, in terms of biodiversity, as a typical rainforest. Today, he has a different message.

Lambshead, an expert on the taxonomy of nematodes at the Natural History Museum in London, has found that the conclusions you draw about biodiversity can vary dramatically, depending on the area over which you measure it.

In 1995, he and Guy Boucher of the Paris Natural History Museum described the diversity of nematodes - worm-like creatures that account for about $80 \%$ of the abundance of animals in seafloor mud - recorded in nearly 200 sediment cores from around the world. They counted up the number of species found in each batch and extrapolated from these samples to estimate that the deep sea is a 'hyperdiverse' environment, containing more than a million species ${ }^{9}$.

But this extrapolation was controversial. The cores had been analysed by different people, so it was unclear how much overlap there was between the species found in different cores. To tackle this problem, Lambshead's PhD student Caroline Brown analysed cores taken along a 3,000-kilometre stretch in the central Pacific ${ }^{10}$. Her results showed that, although every core was very diverse, a similar pattern of species repeated itself from sample to sample. In retrospect, says Lambshead, this shouldn't be that surprising: explorations by research submersibles have revealed that the deep-sea environment varies little from place to place.

Based on Brown's evidence, Lambshead and Boucher officially downgraded their estimate of the diversity of the deep ocean in a guest editorial in the Journal of Biogeography ${ }^{11}$ last year. Lambshead is now doing further work with John Gray of the University of Oslo in Norway, who had independently questioned the idea of deep-sea hyperdiversity ${ }^{12}$. Their unpublished data confirm that the same picture applies to polychaete worms - the next most abundant creatures in the mud.

Lambshead's repudiation of deep-sea hyperdiversity has met with some resistance from marine ecologists, who had eagerly embraced the concept. Environmentalists had also used the theory to argue that it is crucially important to conserve every segment of the deep ocean. Conservation is still important, says Lambshead, and the deep ocean still diverse - just not hyperdiverse. 